Original research article

\title{
Trends in overweight and obesity prevalence among school- aged children in Slovakia, from 2006 to 2014
}

\author{
Martina Bašková ${ }^{*}$, Tibor Baška ${ }^{2}$, Jana Holubčíková ${ }^{3,4}$ \\ ${ }^{1}$ Comenius University in Bratislava, Jessenius Faculty of Medicine in Martin, Department of Midwifery, Martin, Slovak Republic \\ ${ }^{2}$ Comenius University in Bratislava, Jessenius Faculty of Medicine in Martin, Department of Public Health, Martin, Slovak Republic \\ ${ }^{3}$ P. J. Šafárik University in Košice, Faculty of Medicine, Department of Health Psychology, Košice, Slovak Republic \\ ${ }^{4}$ Masaryk University, Faculty of Social Studies, Institute for Research of Children, Youth and Family, Brno, Czech Republic
}

\begin{abstract}
Objectives: The study analyses trends of overweight and obesity among Slovak adolescents aged 11, 13 and 15 years from 2006 to 2014. Methods: The study employs data from the Health Behaviour in School Aged Children study collected in 2006, 2010 and 2014 in Slovakia. We analysed the data from the representative sample of 10,615 adolescents. Body mass index (BMI) was calculated based on the selfreported weight and height. WHO Child Growth Standards were used to categorise age and gender specific BMI cut-off points as normal weight, overweight and obese.

Results: The prevalence of overweight and obesity among Slovak adolescents from 2006 to 2014 ranged between 2.0\% (11-year old girls in 2006) and 15.9\% (15-year old boys in 2010). It increased significantly from 2006 to 2010 in almost all subgroups, except in 11-year old girls. 13 and 15-year old boys dominated above girls in all three surveys.

Conclusions: The remarkable increase of overweight and obesity in Slovak adolescents can be associated with a simultaneous decline of physical activity. We assume these changes reflect the expansion of screen-based activities, namely information technologies. These changes highlight a need for effective preventive measures focused on adolescents.
\end{abstract}

Keywords: Adolescent; HBSC study; Obesity; Overweight; Trends

\section{Introduction}

The World Health Organization (WHO) considers overweight and obesity to be worldwide epidemics affecting both developed and developing countries. Taking into account its global growth within recent decades and its impact on population health, it ranks among the most prominent contemporary public health issues (Onis et al., 2010). Prevalence of obesity and overweight in adolescents doubled between 1980 and 2014 and currently includes more than 1.9 billion people, i.e. $11 \%$ of males and $25 \%$ of women worldwide (Martínez et al., 2012; Masuet-Aumatell et al., 2013).

Obesity in children and adolescents presents a special issue. It increases the risk of several diseases and also brings mental problems such as low self-confidence, depression and eating disorders (Pulgarón, 2013). Moreover, obesity in childhood frequently continues until adulthood, leading to respective health consequences (Mamun et al., 2009).

Although the onset of obesity is - to a certain level genetically determined, inappropriate eating habits and insufficient physical activity rank among its most significant aetiological factors (Prentice-Dunn and Prentice-Dunn, 2012).
Analysis of epidemiological data on obesity and related factors makes it possible to evaluate the situation in the adolescent population and contributes to understanding its determinants as starting points for the designing of community-based preventive intervention in this target group.

Health Behaviour in School Aged Children (HBSC) is one of the first international cross-sectional studies focused on the target group of schoolchildren. It started as an initiative of three countries in 1983 (United Kingdom, Finland and Norway). Currently, it is conducted under the auspices of WHO and comprises 44 countries of Europe and North America. Its goals include the monitoring of health and health related behaviour of 11, 13 and 15year old schoolchildren in their social context, as well as the understanding of the mechanisms influencing differences and changes of their health and risk behaviour. Surveys within the study are carried out every four years. Standard methods provide representative and internationally comparable epidemiologic data.

This work analyses representative epidemiologic data on overweight and obesity in schoolchildren in Slovakia obtained through HBSC surveys carried out in 2006, 2010 and 2014. Its goal is to analyse the trend of the prevalence of overweight and obesity in Slovak adolescents aged 11, 13 and 15 years old in the given time period.

\footnotetext{
* Author for correspondence: Martina Bašková, Comenius University in Bratislava, Jessenius Faculty of Medicine, Department of Midwifery, 5 Malá Hora; 03601 Martin, Slovak Republic; e-mail: baskova@jfmed.uniba.sk http://doi.org/10.32725/kont.2018.004

Submitted: 2018-07-26 • Accepted: 2018-10-16 • Prepublished online: 2019-01-11 


\section{Materials and methods}

\section{Sample}

We used data from the Health Behaviour in School-aged Children (HBSC) study conducted in 2006, 2010 and 2014 in Slovakia ( $N=2874,3669$ and 4073 respectively). The samples were created to obtain representative data on 11, 13 and 15year old adolescents. Two-step sampling was used, in keeping with the standardized research protocol. In the first step, from the official list of all schools - provided from the Slovak Institute of Information and Prognosis for Education - participating ones were randomly selected with probability proportional to size. The sample of schools was stratified by region (eight administrative self-governing regions) and type of school (elementary schools as well as eight-year grammar schools). In the second step, within the participating schools, classes were randomly selected and questionnaire data were collected in pupils attending these selected classes. The study was based on surveys administrated in schools by professional fieldworkers or by trained research assistants following standardized survey protocol. Data were collected via self-administered paper questionnaires. Participation in the study was fully voluntary and anonymous, with no explicit incentives provided for participation. Parents were informed about the study via the school administration and could opt out if they disagreed with their child's participation.

\section{Measures}

The respondents were asked to report their weight $(\mathrm{kg})$ and height $(\mathrm{cm})$. We calculated body mass index by dividing the weight in kilograms by the square of the height in meters (kg/ $\mathrm{m}^{2}$ ) for each respondent. The respondent's weight status was categorised by means of the WHO Child Growth Standards (WHO, 2017). We used age and gender specific BMI cut-off points to categorise the respondents as normal weight, overweight and obese.

\section{Statistical analyses}

First, the description of the sample was provided. The prevalence of overweight and obesity stratified by gender, age and survey was computed. Second, using Chi-square test, we assessed the trends in overweight and obesity prevalence stratified by gender, age and survey. Similarly, we assessed gender differences stratified by age and survey. Analyses were carried out using SPSS v 21 statistical software.

\section{Results}

The study sample consisted of the representative sample of 10,615 adolescents aged 11, 13 and 15 years. The descriptive statistics are presented in Table 1 . In general, the prevalence of overweight and obesity among Slovak adolescents from 2006 to 2014 ranged between 2.0\% (11-year old girls in 2006) and $15.9 \%$ (15-year old boys). In all three surveys, the prevalence increased with age (both in boys and girls). Similarly, the prevalence of overweight and obesity was significantly higher among boys (except 11-year old respondents) in 2006 and 2014. The analysis of changes over time showed that the number of adolescents reporting overweight and obesity increased significantly in all subsamples between 2006 and 2010 (except 11-year old girls). On the other hand, no significant changes occurred between 2010 and 2014. (Table 2).

\section{Discussion}

The results demonstrate an increasing trend of overweight and obesity among adolescents in Slovakia as well as predominance in boys over girls. The increase is consistent with the overall development in Europe. As seen in HBSC results, a similar trend can be identified in most countries (Inchley et al., 2016). Similarly, the predominance of boys is consistent with other findings as well (Gomula et al., 2015; Shirasawa et

\begin{tabular}{|c|c|c|c|}
\hline & $\begin{array}{c}2006 \\
N(\%)\end{array}$ & $\begin{array}{c}2010 \\
N(\%)\end{array}$ & $\begin{array}{l}2014 \\
N(\%)\end{array}$ \\
\hline \multicolumn{4}{|l|}{ Gender } \\
\hline Boy & 1311 (45.6) & 1706 (46.5) & 1973 (48.5) \\
\hline Girl & $1563(54.4)$ & $1963(53.5)$ & $2100(51.6)$ \\
\hline \multicolumn{4}{|l|}{ Age category } \\
\hline 11 & $942(32.8)$ & $894(24.4)$ & $1147(28.2)$ \\
\hline 13 & $1007(35.0)$ & $1438(39.2)$ & 1709 (42.0) \\
\hline 15 & $925(32.2)$ & $1337(36.4)$ & 1217 (29.9) \\
\hline \multicolumn{4}{|l|}{ BMI category } \\
\hline Normal weight & 2749 (95.7) & 3396 (92.6) & 3755 (92.2) \\
\hline Overweight & $110(3.8)$ & $219(6.0)$ & $252(6.2)$ \\
\hline Obesity & $15(0.5)$ & $54(1.5)$ & 66 (1.6) \\
\hline Total N (\%) & $2874(100)$ & 3669 (100) & $4073(100)$ \\
\hline
\end{tabular}

Table 2. The prevalence of overweight and obesity stratified by gender, age and date of survey; trends of overweight and obesity from 2006 to 2014, odds ratios (OR) and 95\% confidence intervals (CI) in parentheses

\begin{tabular}{|c|c|c|c|c|c|c|c|c|c|c|}
\hline \multirow[b]{2}{*}{ Age } & \multirow[b]{2}{*}{ Gender } & \multicolumn{3}{|c|}{$\begin{array}{c}\text { Prevalence of overweight and } \\
\text { obesity } N(\%)\end{array}$} & \multicolumn{3}{|c|}{$\begin{array}{l}\text { Differences between surveys } \\
\qquad(p \text { value })\end{array}$} & \multicolumn{3}{|c|}{$\begin{array}{c}\text { Gender differences } \\
\text { ( } p \text { value })\end{array}$} \\
\hline & & 2006 & 2010 & 2014 & 2006 vs. 2010 & 2010 vs. 2014 & 2006 vs. 2014 & 2006 & 2010 & 2014 \\
\hline \multirow{2}{*}{11 years } & boys & $14(2.9)$ & $29(6.0)$ & $46(6.8)$ & 0.022 & 0.565 & 0.003 & \multirow{2}{*}{0.320} & \multirow{2}{*}{0.011} & \multirow{2}{*}{0.076} \\
\hline & girls & $11(2.0)$ & $16(2.8)$ & $30(4.5)$ & 0.363 & 0.104 & 0.013 & & & \\
\hline \multirow{2}{*}{13 years } & boys & $31(6.4)$ & $87(11.8)$ & $105(11.2)$ & 0.002 & 0.677 & 0.004 & \multirow{2}{*}{0.014} & \multirow{2}{*}{$<0.001$} & \multirow{2}{*}{0.009} \\
\hline & girls & $19(3.2)$ & $46(5.7)$ & $76(7.7)$ & 0.030 & 0.101 & $<0.001$ & & & \\
\hline \multirow{2}{*}{15 years } & boys & $48(10.3)$ & $116(15.9)$ & $116(15.8)$ & 0.006 & 0.937 & 0.008 & \multirow{2}{*}{0.005} & \multirow{2}{*}{$<0.001$} & \multirow{2}{*}{0.001} \\
\hline & girls & $29(5.5)$ & $64(8.6)$ & 67 (9.9) & 0.041 & 0.376 & 0.005 & & & \\
\hline
\end{tabular}


al., 2015; Suder et al., 2017). Considering the development of the situation in the European context, the position of Slovakia has changed within the given time period. While in 2006 Slovakia ranked among the countries with the lowest prevalence of overweight and obesity, it moved in the next surveys up to higher values. Thus the Slovakia results in 2014 were close to the HBSC average (Currie et al., 2008, 2012; Inchley et al., 2016).

The remarkable increase of the prevalence between 2006 and 2010 and almost no changes between 2010 and 2014 deserve closer attention. Evaluation of indicators related to obesity and surveyed in HBSC in Slovakia can help us to identify possible reasons for such an interesting development (Fig. 1). The prevalence of irregular eating (skipping breakfast) and daily consumption of fruits did not change significantly within the given period. Consumption of sweetened soft drinks even decreased after 2006. On the other hand, the remarkable decline of physical activity after 2006 corresponds with the development of overweight and obesity prevalence found in our analysis. A similar association was found in Czechia when ana- lysing changes of nutritional status and related factors among adolescents after 2002 (Sigmund et al., 2018; Sigmundová et al., 2014). In addition, a decline of physical activity among Czech adolescents was observed namely in lower socioeconomic groups (Sigmund et al., 2018), indicating that the issue can further contribute to socially determined health inequality. Reduced physical activity can also be considered as a manifestation of changed leisure time activities. However, watching of TV declined during the same period. This paradox can be explained by the massive entrance of mobile information technologies after the millennium. Their use among adolescents leads to reduced physical activity resulting in increased risk of obesity (Pulgarón, 2013). At the same time, TV watching, which dominated in the 1990s (Inchley et al., 2017), has been gradually replaced by the use of mobile technologies with internet connection (Atkin et al., 2013; Carson et al., 2016; Reid et al., 2016). Moreover, in the same period, social networks, as a new phenomenon, massively entered society (Facebook Newsroom, 2018).
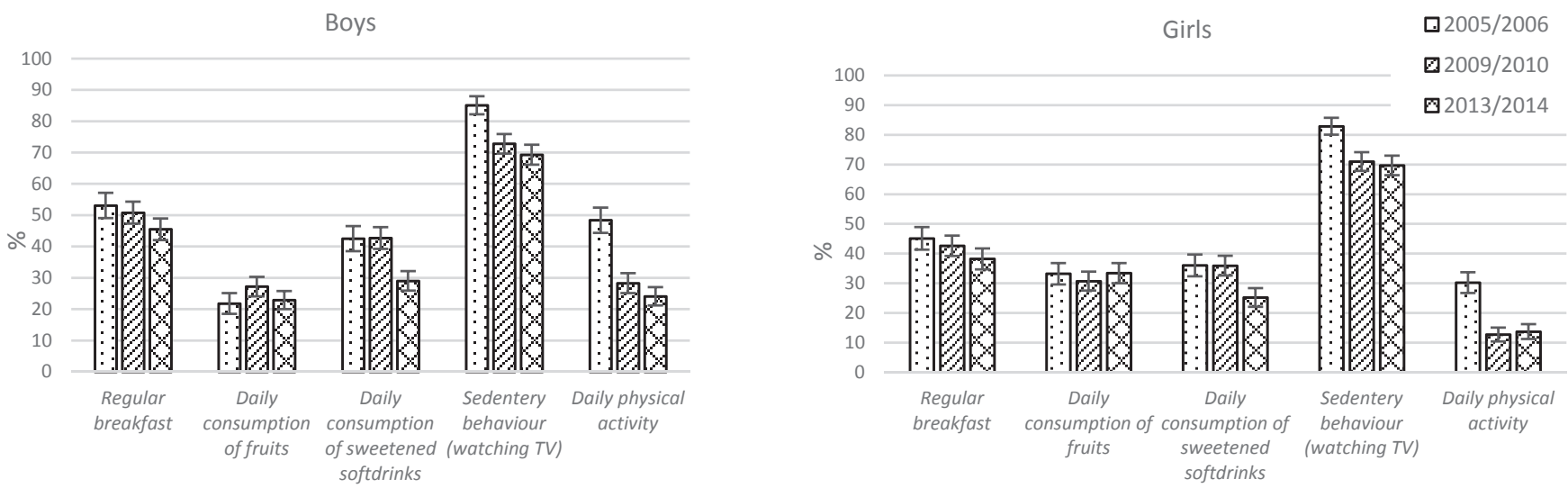

Fig. 1. Prevalence of selected factors related to obesity in 15-year old children in Slovakia, HBSC Slovakia 2005/2006, 2009/2010, 2013/2014. Error bars present confidence intervals 95\% (Currie et al., 2008; 2012; Inschley et al., 2016).

Another possible explanation lies in the increasing trend of caesarean deliveries, which is higher than average age compared to most European countries. Some studies indicate a causal association between caesarean delivery and the risk of obesity in the child (Darmasseelane et al., 2014; Li et al., 2013).

Therefore, the issue seems to be rather complex and its better understanding needs further multidisciplinary approached research.

\section{Strengths and limitations}

The major strength of the study is the large and representative sample for Slovak adolescents. The limitation is the use of self-reports. The BMI category of respondents was identified based on self-reported weight and height - which can be inaccurate or biased. We should also keep in mind the possible false negative insignificance of some differences due to the small number of positive cases in some subsamples - such as 11-year old girls. On the other hand, a very similar pattern can be seen in other subgroups including higher numbers of cases, as well.

\section{Ethical standards disclosure}

The study was approved by the Ethics Committee of the Medical Faculty at Pavol Jozef Safarik University in Kosice. It was therefore performed in accordance with the ethical standards laid down in the 1964 Declaration of Helsinki and its later amendments. Parents of respondents were informed about the study via the school administration; they gave their informed consent prior to the inclusion of their children in the study and could opt out if they disagreed with their child's participation. Participation in the study was fully voluntary and anonymous with no explicit incentives provided for participation.

\section{Conclusions}

Prevalence of overweight and obesity in Slovakia increased within the last decade - similar to most European countries. The passive spending of leisure time using mobile information technologies can be one of the reasons. The promotion of physical activity seems essential to prevent an impact of obesity on population health. 


\section{Conflict of interests}

The authors have no conflict of interests to disclose.

\section{Acknowledgements}

The authors acknowledge the support of the Slovak Research and Development Support Agency (APVV-15-0012, APVV
0032-11), the Scientific Grant Agency of the Ministry of Education, Science, Research and Sport of the Slovak Republic, the Slovak Academy of Sciences (Reg. No. 1/0981/15) and the Czech Science Foundation (GA15-05696S).

\section{Trendy prevalence nadváhy a obezity dětí ve školním věku na Slovensku od roku 2006 do roku 2014}

\section{Souhrn}

Cíle: Studie analyzuje trendy nadváhy a obezity u slovenských adolescentů ve věku 11, 13 a 15 let od roku 2006 do roku 2014. Metodika: Studie využivá údaje ze studie „Zdravé chování dětí ve školním věku“ shromážděné v letech 2006, 2010 a 2014 na Slovensku. Analyzovali jsme údaje z reprezentativního vzorku o 10615 dospívajících. Index tělesné hmotnosti (BMI) byl vypočítán na základě vlastní hmotnosti a výšky. Standardy WHO pro růst dítěte byly použity ke kategorizaci věkových a pohlavních specifických bodů BMI, tj. normální hmotnosti, nadváhy a obezity.

Výsledky: Prevalence nadváhy a obezity mezi slovenskými adolescenty v letech 2006 až 2014 se pohybovala v rozmezí 2,0 \% (11leté dívky v roce 2006) a 15,9 \% (15letí chlapci v roce 2010). V letech 2006 až 2010 se výrazně zvýšila téměř ve všech podskupinách, s výjimkou 11letých dívek; 13letí a 15letí chlapci dominovali ve všech třech průzkumech.

Závěry: Pozoruhodný nárůst nadváhy a obezity u slovenských dospívajících může být spojen se současným poklesem fyzické aktivity. Předpokládáme, že tyto změny odrážejí rozšiření screen aktivit, zejména informačních technologií. Tyto změny zdůrazňují potřebu účinných preventivních opatření zaměřených na adolescenty.

Klíčová slova: adolescent; nadváha; trendy; obezita; studie HBSC

\section{References}

1. Atkin AJ, Corder K, van Sluijs EM (2013). Bedroom media, sedentary time and screen-time in children: a longitudinal analysis. Int J Behav Nutr Phys Act 10: 137. DOI: 10.1186/1479-5868-10-137.

2. Carson V, Hunter S, Kuzik N, Gray CE, Poitras VJ, Chaput JP, et al. (2016). Systematic review of sedentary behaviour and health indicators in school-aged children and youth: an update. Appl Physiol Nutr Metab 41(6 Suppl. 3): S240-S265. DOI: 10.1139/ apnm-2015-0630.

3. Currie C, Nic Gabhainn S, Godeau E, Roberts C, Smith R, Currie D, et al. (2008). Inequalities in young people's health: HBSC international report from the 2005/06 Survey, WHO.

4. Currie C, Zanotti C, Morgan A, Currie D, de Looze M, Roberts Ch, et al. (2012). Social determinants of health and well-being among young people. Health Behaviour in Schoolaged Children (HBSC) study: international report from the 2009/2010 survey, WHO.

5. Darmasseelane K, Hyde MJ, Santhakumaran S, Gale C, Modi N (2014). Mode of delivery and offspring body mass index, overweight and obesity in adult life: a systematic review and meta-analysis. PLoS One 9(2): e87896. DOI: 10.1371/journal. pone.0087896.

6. Facebook Newsroom (2018). Company Info. [online] [cit. 201801-08]. Available from: https://newsroom.fb.com/companyinfo/

7. Gomula A, Nowak-Szczepanska N, Danel DP, Koziel S (2015). Overweight trends among Polish schoolchildren before and after the transition from communism to capitalism. Econ Hum Biol DOI: 10.1016/j.ehb.2015.09.002.

8. Inchley J, Currie D, Jewell J, Breda J, Barnekow V (2017). Adolescent obesity and related behaviours: trends and inequalities in the WHO European Region, 2002-2014 Observations from the Health Behaviour in School-aged Children (HBSC) WHO collaborative cross-national study, WHO Regional Office for Europe, Copenhagen.
9. Inchley J, Currie D, Young T, Samdal O, Torsheim T, Augustson L, et al. (2016). Growing up unequal: gender and socioeconomic differences in young people's health and well-being. HBSC Study: International Report From The 2013/2014 Survey, WHO

10. Li HT, Zhou YB, Liu JM (2013). The impact of cesarean section on offspring overweight and obesity: a systematic review and meta-analysis. Int J Obes (Lond) 37(7): 893899. DOI: 10.1038/ ijo.2012.195.

11. Mamun AA, O'Callaghan MJ, Cramb SM, Najman JM, Williams GM, Bor W (2009). Childhood behavioral problems predict young adults' BMI and obesity: evidence from a birth cohort study. Obesity (Silver Spring) 17(4): 761-766. DOI: 10.1038/oby.2008.594.

12. Martínez-Vizcaíno V, Solera Martínez M, Notario Pacheco B, Sánchez López M, García-Prieto JC, Torrijos Niño C, et al. (2012). Trends in excess of weight, underweight and adiposity among Spanish children from 2004 to 2010: The Cuenca Study. Public Health Nutr 15(12): 2170-2174. DOI: 10.1017/ S1368980012003473.

13. Masuet-Aumatell C, Ramon-Torrell JM, Banqué-Navarro M, Dávalos-Gamboa Mdel R, Montaño-Rodríguez SL (2013). Prevalence of overweight and obesity in children and adolescents from Cochabamba (Bolivia); a cross-sectional study. Nutr Hosp 28(6): 1884-1891. DOI: 10.3305/nutr hosp. v28in06.6881.

14. Onis M, Blössner M, Borghi E (2010). Global prevalence and trends of overweight and obesity among preschool children. Am J Clin Nutr 92(5): 1257-1264. DOI: 10.3945/ajcn.2010.29786.

15. Prentice-Dunn H, Prentice-Dunn S (2012). Physical activity, sedentary behavior, and childhood obesity: a review of cross-sectional studies. Psychol Health Med 17(3): 255-273. DOI: 10.1080/13548506.2011.608806.

16. Pulgarón ER (2013). Childhood obesity: a review of increased risk for physical and psychological comorbidities. Clin Ther 35(1): 18-32. DOI: 10.1016/j.clinthera.2012.12.014.

17. Reid Chassiakos YL, Radesky J, Christakis D, Moreno MA, Cross C (2016). Children and Adolescents and Digital Media. Pediatrics 138(5): e20162593. DOI: 10.1542/peds.2016-2593. 
18. Shirasawa T, Ochiai H, Nanri H, Nishimura R, Ohtsu T, Hoshino H, et al. (2015). Trends of Underweight and Overweight/Obesity Among Japanese Schoolchildren From 2003 to 2012, Defined by Body Mass Index and Percentage Overweight Cutoffs. J Epidemiol 25(7): 482-488. DOI: 10.2188/jea.JE20140144.

19. Sigmund E, Badura P, Sigmundová D, Voráčová J, Zacpal J, Kalman M, et al. (2018). Trends and correlates of overweight/ obesity in Czech adolescents in relation to family socioeconomic status over a 12-year study period (2002-2014). BMC Public Health 18(1): 122. DOI: 10.1186/s12889-017-5013-1.
20. Sigmundová D, Sigmund E, Hamrik Z, Kalman M (2014). Trends of overweight and obesity, physical activity and sedentary behaviour in Czech schoolchildren: HBSC study. Eur J Public Health 24(2): 210-215. DOI: 10.1093/eurpub/ckt085.

21. Suder A, Gomula A, Koziel S (2017). Central overweight and obesity in Polish schoolchildren aged 7-18 years: secular changes of waist circumference between 1966 and 2012. Eur J Pediatr 176(7): 909-916. DOI: 10.1007/s00431-017-2938-4.

22. WHO (2017). The WHO Child Growth Standards. [online] [cit. 2017-09-21]. Available from: http://www.who.int/childgrowth/ en/ 